UDC 378.1

DOI https://doi.org/10.24919/2308-4863/35-5-41

\section{Larysa SVYRYDOVA, orcid.org/0000-0002-9762-4092 \\ Lecturer at the Department of English for Engineering № 2 National Technical University of Ukraine "Igor Sikorsky Kyiv Polytechnic Institute" (Kyiv, Ukraine) kpi.sviridova@gmail.com}

Neonila KUTSENOK, orcid.org/0000-0001-7111-0088

Lecturer at the Department of English for Engineering № 2 National Technical University of Ukraine "Igor Sikorsky Kyiv Polytechnic Institute" (Kyiv,Ukraine)nila15@ukr.net

Iryna STAVYTSKA, orcid.org/0000-0003-4915-0141

Candidate of Pedagogical Sciences, Associate Professor at the Department of English for Engineering № 2 National Technical University of Ukraine "Igor Sikorsky Kyiv Polytechnic Institute" (Kyiv,Ukraine)iryna_stavytska@ukr.net

Oksana KORBUT, orcid.org/0000-0001-6671-3925 Senior Lecturer at the Department of English for Engineering № 2 National Technical University of Ukraine "Igor Sikorsky Kyiv Polytechnic Institute" (Kyiv,Ukraine) korbut@bigmir.net

\title{
FROM THE EXPERIENCE OF DEVELOPMENT OF ENGLISH INTERACTIVE ELECTRONIC STUDY GUIDE FOR TECHNICAL STUDENTS
}

This article is devoted to the development and application of interactive electronic textbook for the third-year students of the specialization «Applied Mechanics» and "Industrial Engineering» in the discipline "English language». The development of science and technology stimulates the need to improve the system of professional training. In today's global digitalized society and our country's integration into the world educational space, the main priorities for the development of the entire education system are modernization and improving the quality of education. In the process of intensive transition of modern society to digital format, universities and other educational institutions are looking for ways to make the learning process more efficient by modifying methods, technologies, materials, etc. to the modern, most understandable and convenient for the student format of learning, one of the key aspects of which is the use of electronic textbooks. It is worth emphasizing the adaptability of this educational resource, which provides the ability to supplement or edit educational content, such as texts or videos of professional subject area in connection with the rapid scientific and technological progress that ensures the relevance of data. The article reveals the significance of integrating the interactive electronic textbooks into the educational process, the interactive platforms, applications and services used in creating the textbook are described in detail and the compliance of this interactive online textbook with the requirements of the new generation educational system is proved. In addition, the authors provide theoretical principles for design and developing of an electronic textbook, considering the specific features, didactic requirements at the stage of design, as well as technical characteristics and tools needed to develop the interactive electronic textbook, also highlight the drawbacks and benefits of using the electronic textbooks in the whole.

The structure of the given e-study guide, developed by the authors of this paper is considered in details, a number of examples of assignments, supported with screenshots and a table, as well as appendixes and useful links are offered to consider in preparing further interactive learning materials of this type.

Key words: interactive electronic textbook, English for professional purposes, Google docs, Quizlet, QR codes, Mind maps. 
Лариса СВИРИДОВА,

orcid.org/0000-0002-9762-4092

викладач кафедри англійської мови технічного спрямування № 2

Національного технічного університету України

«Київський політехнічний інститут імені Ігоря Сікорського»

(Київ, Україна) kpi.sviridova@gmail.com

Неоніла КУЦЕНОК,
огсіd.оrg/0000-0001-7111-0088
викладач кафедри англійської мови технічного спрямування № 2
Начіонального технічного університету Украйни
«Киӥвський політехнічний інститут імені Ігоря Сікорського»

(Київ, Україна)nila15@ukr.net

Ірина СТАВИЦЬКА,

orcid.org/0000-0003-4915-0141

кандидат педагогічних наук,

дочент кафедри англійської мови технічного спрямування № 2

Начіонального технічного університету України

«Київський політехнічний інститут імені Ігоря Сікорського»

(Київ, Україна) iryna_stavytska@ukr.net

\begin{abstract}
Оксана КОРБУТ,
orcid.org/0000-0001-6671-3925

старший викладач кафедри англійської мови технічного спрямування № 2

Начіонального технічного університету України

«Київський політехнічний інститут імені Ігоря Сікорського»

(Київ, Україна) korbut@bigmir.net
\end{abstract}

\title{
ІЗ ДОСВІДУ РОЗРОБЛЕННЯ ІНТЕРАКТИВНОГО ЕЛЕКТРОННОГО ПОСІБНИКА 3 АНГЛІЙСЬКОЇ МОВИ ДЛЯ СТУДЕНТІВ НЕМОВНИХ СПЕЦІАЛЬНОСТЕЙ
}

\footnotetext{
Статтю присвячено питанню розроблення та застосування інтерактивного електронного підручника для студентів третього курсу напрямів підготовки «Прикладна механіка» та «Галузеве машинобудування» з дисиипліни «Англійська мова». Розвиток науки і техніки стимулює необхідність удосконалення системи професійної підготовки фахівиів. В умовах сучасного глобального інформаційного суспільства $і$ входження краӥни у світовий освітній простір основними пріоритетами розвитку всієї системи освіти стають модернізація $і$ підвищення якості освіти У прочесі інтенсивного переходу сучасного суспільства до ичифрового формату університети та інші навчальні заклади шукають способи зробити процес навчання більш ефективним, модифікуючи методи, технології, матеріали тощо до сучасного, найбільш зрозумілого $i$ зручного для студента формату навчання, одним із ключових аспектів якого є застосування електронних підручників. Варто підкреслити адаптивність даного освітнього ресурсу, щзо передбачає можливість додавання або редагування навчального контенту, наприклад текстів або відеофайлів професійної тематики у зв'язку зі швидко крокуючим науково-технічним прогресом, щуо забезпечує актуальність даних. У статті розкрито актуальність інтегрування інтерактивного електронного підручника в освітній процес, детально описано використані під час створення підручника інтерактивні платформи, додатки та сервіси та доведено відповідність цьвого інтерактивного онлайн-інструментарію вимогам освітньої системи нового покоління. Окрім того, авторами надано теоретичні засади створення електронного підручника, розглянуто специфічні особливості, дидактичні вимоги, на які необхідно орієнтуватися під час його планування, технічні характеристики та інструменти, необхідні для розроблення інтерактивного електронного підручника, а також висвітлено недоліки та переваги.

Структуру електронного підручника, розроблену авторами иієї статті, детально розглянуто, запропоновано велику кількість прикладів завдань, скріншоти, таблиці та малюнки, а також додатки та корисні посилання, які необхідно враховувати у підготовці подальших інтерактивних навчальних матеріалів такого типу.

Ключові слова: інтерактивний електронний підручник, англійська мова професійного спрямування, Gооgleдокументи, Quizlet, QR codes, Mind maps.
} 
Problem statement. Educational system of Ukraine is going through the challenging period of structural, as well as contextual alteration. Fastdeveloping information technologies, introduction of new related products, alterations in the world economy and "digitalizing" of the modern society inevitably lead to the need of competent specialists. Consequently, higher educational establishments seek for the ways to remain on the cutting edge in training highly demanded on the labor market graduates, providing them with up-to-date and multifunctional skills, able to think critically and innovatively. Moreover, in times of globalization and active European integration the command of English language is a kind of mandatory attribute for the young specialists. Thus, to meet the requirements of the modern society, one of the most crucial tasks of educational establishments today is searching for the new, adaptive and more effective means of teaching with application of innovative technologies. Undoubtedly, it concerns the teaching of foreign languages for specific purposes, particularly, English language, or ESP.

As practice shows, using digital learning tools with application of multimedia and interactive format is gaining popularity in foreign language teaching practice, otherwise, their incorporation in development of digital (may also be called as electronic) textbooks or study guides for ESP learners, namely, for students of technical faculties have not been studied yet and widely spread as well.

Review or recent research and publications. Theoretical and practical aspects of developing of electronic textbooks (study guides) were studied by Ukrainian and foreign scientists, in particular L. Gryzun, M. Belyaev, V. Vymyatin, S. Grigoriev, A. Bashmakov, S. Sysoeva, M. Zholdak, Kessler G. and others. The questions relevant to the introduction of electronic technologies into the educational process, including various aspects of the organization and use of electronic textbooks, attacted attention of such researchers as V. Volynsky, V. Madzigon, O. Hrytsenchuk, I. Kuzbyt. Among foreign scientists, involved in studying the practicability of implication of the Internet resources for educational purposes one can mention Eady M J., Locker L., Hill J. R., Wiley D., Miller N., Mills S.

Various online platforms and services, used to empower the effectiveness of the foreign language learning were examined. The works of Glowacki et al., Marchenko and Tymoschuk; Synekop O. (27), (23), Bevz et al. (24); Wright B. (28), Sherman J., Thornbury S. (34), Law C., Robertson C., Green T. proved the benefits of application of, for example, games, educational videos, Quick Response codes, Web-quests in the learning process.

The aim of the paper is twofold: to reveal the peculiarities of designing, development and further implementation of interactive electronic textbook and to present the model of design and arrangement of e-study guide on the example of the authors 'work "English for Engineering Students: inner parts of machines".

The Main Body. From the abovementioned it becomes clear that the e-textbook (or study guide) is a learning tool with enhanced capabilities compared to the traditional edition of the textbook due to its interactivity properties. It creates tremendous advantages by allowing students along with educational texts to work with additional illustrative materials. These are applications, online services, videos, instructions, diagrams, tables, encyclopedias and reference materials etc. According to Kadimiia M., electronic textbook gives the possibility to solve the following basic pedagogical tasks, as:

- initial acquaintance with the subject, mastering its basic concepts and structures;

- basic training at different levels in compliance with the current curriculum;

- development of skills and abilities of typical practical tasks within the given discipline;

- development of analysis and decision-making skills in non-standard (atypical) issues;

- control and assessment at all levels of knowledge and skills;

- fostering of the information-retrieval activities (Kademiia M, Shestopalyuk O., 2007).

Having examined the benefits of e-textbooks, the authors highlighted the most crucial ones, namely:

- in the e-textbook the clarity of the presentation of the material is higher than in the printing. It contains not only textual and graphical information, but also audio and video fragments that allow to individualize training and, unlike regular (printed) textbook exhibits interactive features (Gaidaienko I. 2016);

- the possibility of interaction between the user and the components of the textbook which can range from simply navigating links to direct participation of the student in process modeling and can be considered in a form that facilitates student-computer dialogue. This principle of interactivity allows students to be actively involved in the learning material working-out (Yesina O., Lingur L., 2012);

- provision of feedback with students. This connection is achieved through the interactive character of student interaction with the environment of the computer textbook and existence of automatic system of knowledge. Thus, at the end of the sections there 
are control questions, exercises, tests, which give the opportunity to obtain information about assimilation of educational material. For the students, this creates the conditions for effective self-learning, self-control, helps to enhance their cognitive activities and motivation;

- the affordability of e-textbooks is higher than that of the printing ones;

- e-textbook are open systems, i.e they can be easily supplemented, changed, modified.

Development of an e-textbook (e-study guide) involves: the selection of literature for the formation of content; content development; processing of texts in each module; implementation of hyperlinks in electronic form; selection, creation and processing of material for multimedia embodiment (video, sound, graphic image) (Koval L., 2010). In addition, a glossary, bibliography, links to Internet sources are provided.

All the above-mentioned peculiarities were taken into account by authors when creating an interactive electronic textbook English for Engineering Students: inner parts of machines. The target audience of this e-textbook - students of the third year of study of the specialization «Applied Mechanics» and «Industrial Engineering» in the discipline «English language». The textbook is designed for 36 academic hours, consists five units and can be used either for practical classes or for independent students' work. The study guide covers five professional topics: «Bearings», «Brakes», «Parts of Machine: Linkage, Spring, Ratchet», «Types of gears», «How different gears work». Each topic contains authentic professional texts in English-language and exercises developed for comprehension check (non-communicative, conditionally communicative, communicative).

Exercises, designed for students of technical specialties are targeted on the formation, development and improvement of skills in listening, reading, speaking (dialogic and monologue speech), writing and translation.

By increasing the students' interest in learning a foreign language and enhancing their motivation to learn, the developed course, on the point of view of authors, will facilitate the efficiency of the educational process.

The e-study guide was created on the Google platform, namely, in Google documents. The choice was determined by various factors, for instance, it is an easy and free way to create interactive learning materials, post documents, share them with other participants of the virtual space; this platform allows multiple users to create and format documents online at the same time; the service supports a large number of popular formats (for example, docx, pdf, odt, rtf, txt, html). It is worth mentioning that the e-guide was on the final stage converted into $p d f$. format, readable from almost all the gadgets, ranging from mobile phone to desktop computer which proves its usability.

As it was mentioned above, it contains five topics: "Bearings", "Brakes", "Parts of machine: linkage, spring, ratchet", Types of gears" and "How different gears work", relevant to students' specialization "Applied mechanics" and "Industrial engineering". There are also such modules as "Introduction", "Appendixes" and "References" (Fig. 1).

Diagram shows the schematic description of the study guide. As it can be seen, each unit consists of nine activities on developing of all language skills and it all is demonstrated as an example on Unit 1. The other units have the same structure. The innovativeness of the authors' e-study guide lies in the practical application of digital Google tools for educational purposes in combination with integrated numerous interactive activities. Most activities are supported with useful links to relevant cites for better comprehension of material or self-assessment.

Let us consider the demonstrative extracts, taken from the e-study guide.

As it is seen from the diagram, the starting activity of every unit is Lead in. One can notice the link to internet site, which students can follow, read the additional information on the subject" (Fig. 2).

When doing Reading section students can first get familiar with new terminology working with Quizlet flashcards. Each hub of new lexical units is transferred on the learning cards for memorizing and students can comfort their lexis drilling. The link to the relevant platform is also attached to the task. Language development consists of six different tasks, one of which was created with the help of MindMup, a Google tool, useful when brainstorming the vocabular of the topic (Fig. 3).

Interactive grammar testing platforms as well as Flipgrid were used in formation Language skills section. Flipgrid is a free and simple application that promotes the development of students' communication skills by creating short video answers and conversations on a given topic. The links to videos from YouTube with detailed consideration of grammar material are attached to this section in every unit (Fig. 4).

Self-assessment of the students is carried out with the application of interactive platforms, websites devoted to grammar, vocabulary revision and testing with immediate feedback (Fig. 5).

Listening and Speaking sections are equipped with references to video files in YouTube and/or tasks, encoded into the $Q R$ codes. Using of Quick Response codes is getting more and more popularity among 




Fig. 1

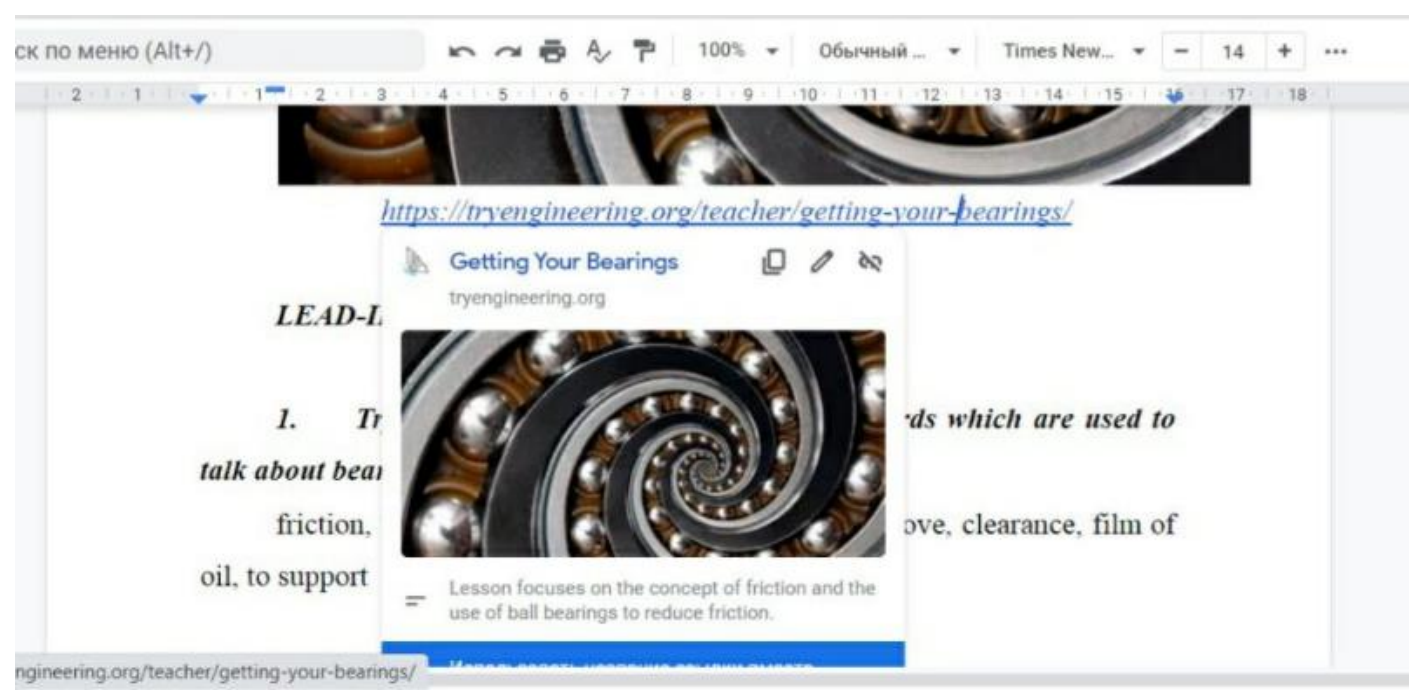

Fig. 2

educators as it becomes possible to embed QR codes into audio/video files, texts, questions, sentences and even word combinations. The authors of the e-study guided under consideration embedded QR codes in key to the exercises either (Fig. 6).

One of the most encouraging ways to use the Internet in foreign language learning is WebQuest technology. Web quest is a kind of delivering of material by setting tasks, and students receive solutions or answers to questions from various Internet resources. This technology was applied in Writing sections along with other assignments otherwise making writing activity more engaging (Fig. 7).

Independent Study section concludes each unit and proposes students to review the material learnt from the unit and test themselves following the links to relevant websites/platforms. QR codes are used to provide correct answers and are attached to the exercises as well.

Conclusion. Thus, the analysis of structural organization, didactic functions, advantages of application and features of electronic textbooks/study guides 
Svyrydova L., Kutsenok N., Stavytska I., Korbut O. From the experience of development...

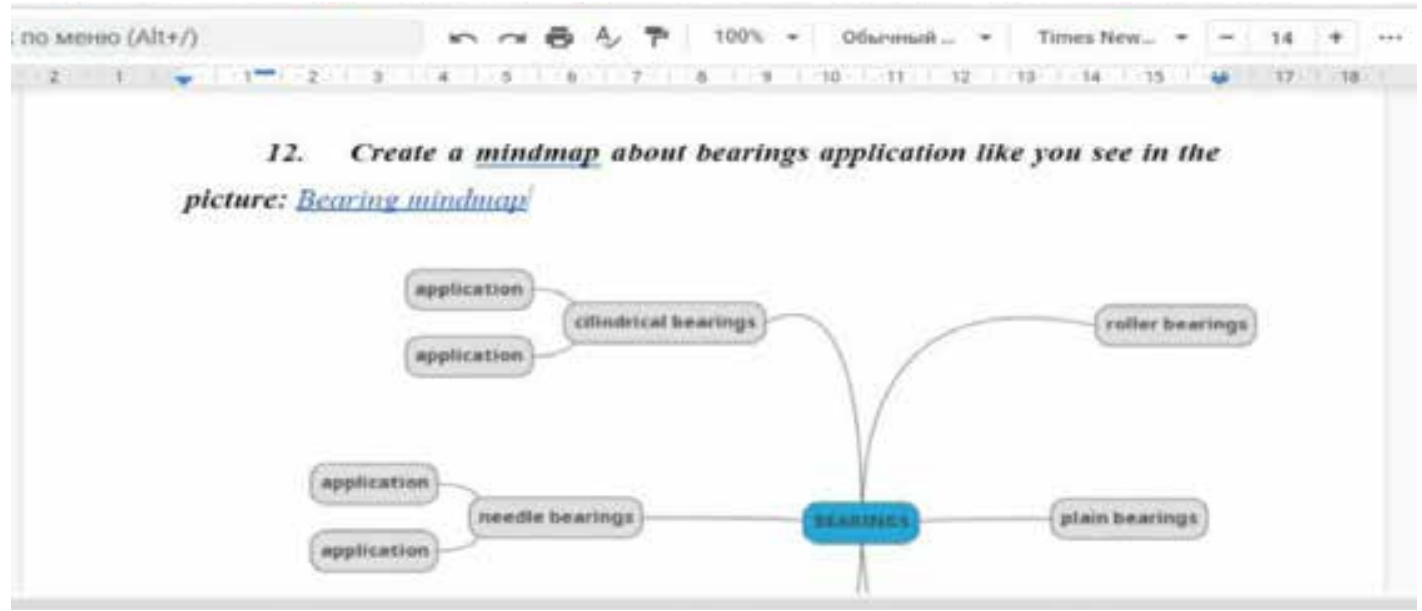

Fig. 3

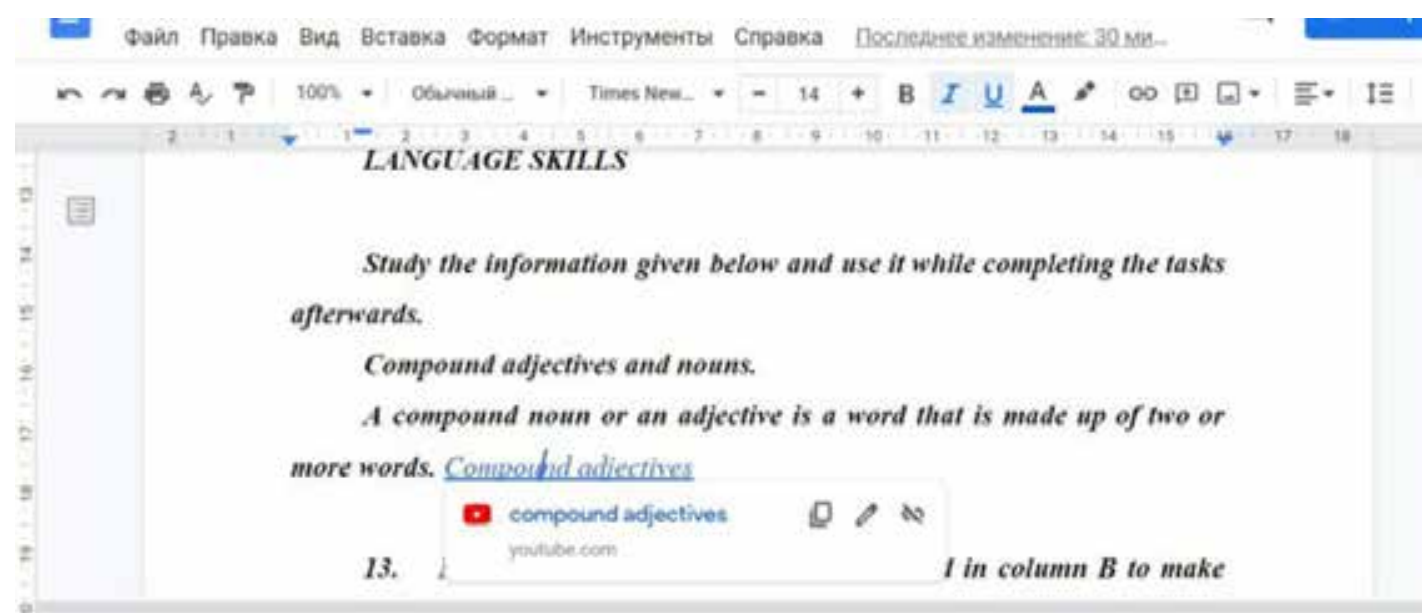

Fig. 4

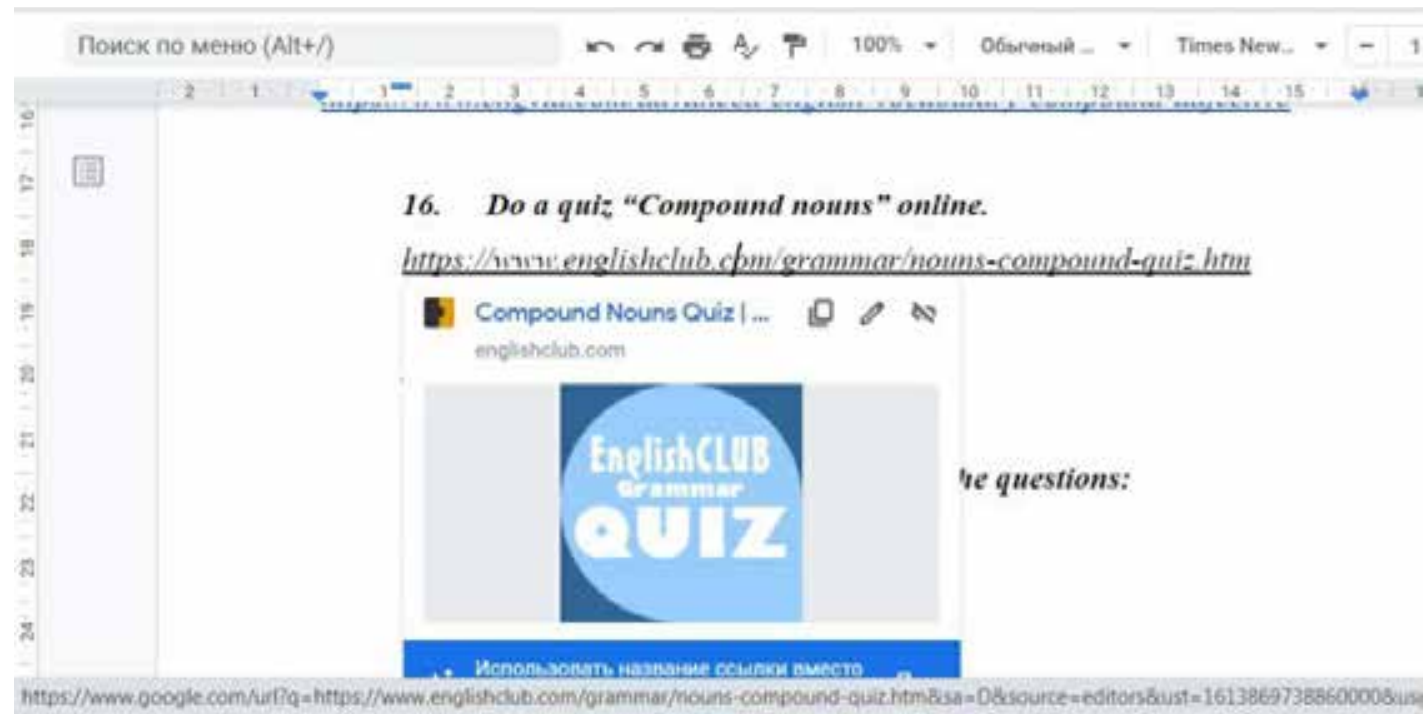

Fig. 5

allow us to conclude that the latter can be considered as an effective means of foreign language learning, which favors the students` engaging in the process of study, providing the development of creative, intuitive thinking; aesthetic education through the use of graphics, multimedia, empowers basic language 


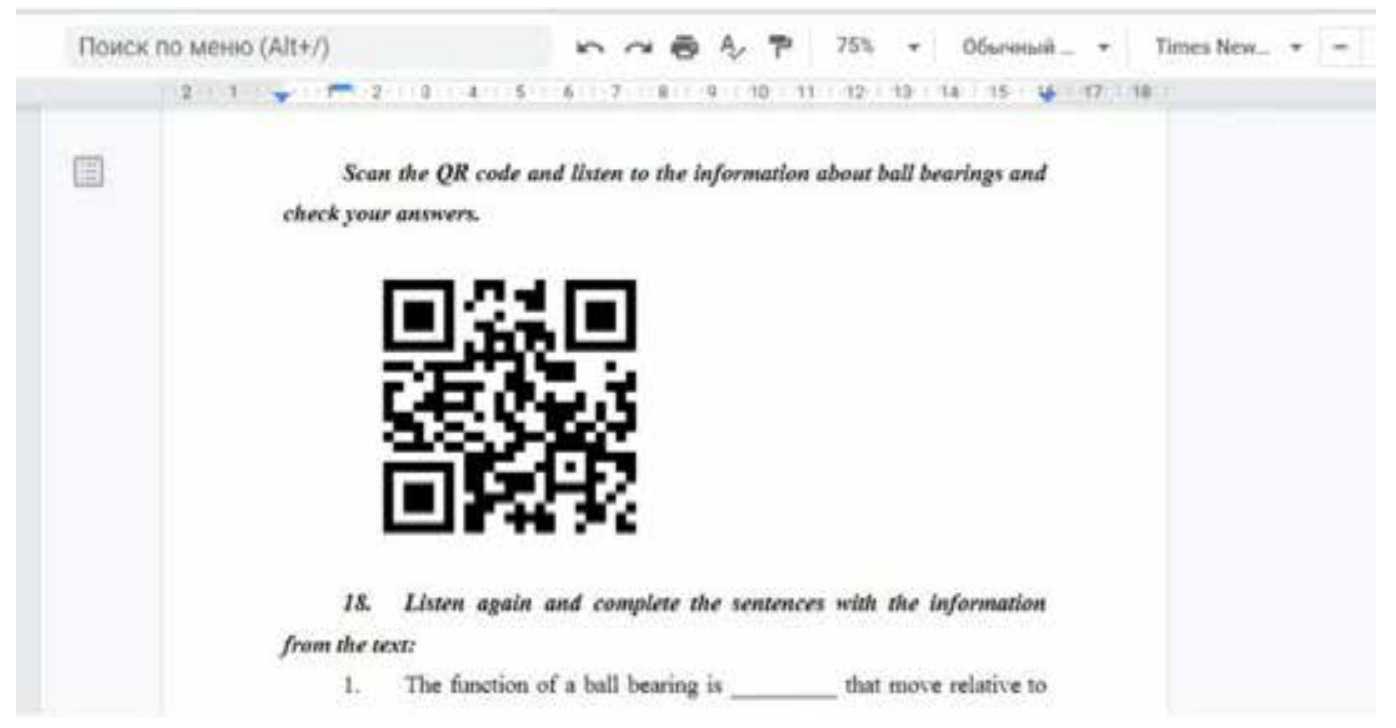

Fig. 6

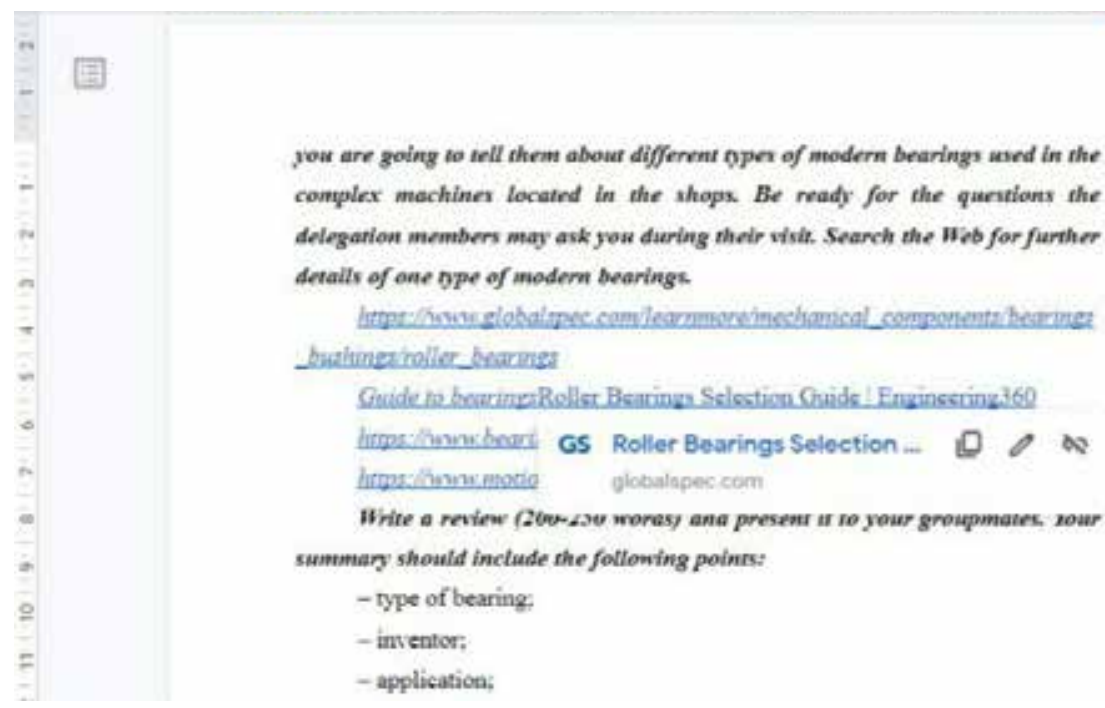

Fig. 7

learning skills due to the authentic content; develops the information competence and information culture.

The increasing of scientists' and educators' interest to the e-textbooks and study guides is caused by the sharp need to search the new and efficient means of education process, facilitated by application of innovative technologies.

The interactive electronic study guide "English for Engineering Students: inner parts of machines", developed by authors of the paper proved its rele- vance which lies in intensive use of Internet services and platforms for formulating the assignments for the educational material. The electronic study guide meets the requirements of the curriculum of the discipline «Foreign language». One of possible issues that may occur in the process of using the e-guide is lack of Internet access, full time or temporary. In this case students, could work only with downloaded pdf-version of the study guide and not able to take advantage from its interactivity.

\section{BIBLIOGRAPHY}

1. Hill J. R., Wiley D., Miller Nelson L., Ha, S. Exploring research on Internet-based learning: from infrastructure to interactions, in D. H. Jonassen (Ed.), Handbook of research for educational communications and technology, New Jersey, Lawrence Erlbaum associates, 2004, p. 433-460.

2. Kessler G. Technology and the future of language teaching. Foreign Language Annals, 51(2), 2018. p. 205-218. URL: https://www.researchgate.net/publication/323330702_Technology_and_the_future_of_language_teaching (date of request 1.02.2021) 
3. Law C., So S. QR codes in education. Journal of Educational Technology Development and Exchange, 3(1), 2010. P. 85-100. URL: http://www.sicet.org/journals/jetde/jetde10/7-So.pdf (date of request 1.02.2021)

4. Mills S. Using the Internet for active teaching and learning. Pearson/Merril/Prentice Hall, 2006. $220 \mathrm{p}$.

5. Mikulski J. 10 Ways to Use QR codes in the Classroom. Classroom in the Cloud. 2011. URL: http://www.classroominthecloud.net/2011/06/10-ways-to-use-qr-codes-in-classroom.html (date of request 2.02.2021)

6. Synekop O. WebQuest as Technology of Differentiated ESP Instruction at University Level. Journal of Teaching English for Specific and Academic Purposes, 8(1), 2020. 043-052. URL: https://doi.org/10.22190/JTESAP2001043S (date of request 2.02.2021)

7. Sherman J., Thornbury S. Using Authentic Video in the Language Classroom (Cambridge Handbooks for Language Teachers). Cambridge University Press, 2010. 288 p

8. Гайдаєнко I. Електронний підручник як новий засіб подання інформації у навчальному процесі. Наукові записки Тернопільського національного педагогічного університету імені Володимира Гнатюка. Серія «Історія». 2016. Вип. 2(3). С. 162-170. URL: http://nbuv.gov.ua/UJRN/NZTNPU_ist_2016_2\%283\%29_33 (дата звернення: 04.02.2021)

9. Єсіна О. Г., Лінгур Л. М. Електронні підручники: переваги та недоліки використання. Вісник соціальноекономічних досліджень. 2012. № 1(44). URL: http://www.nbuv.gov.ua/old_jrn/Soc_Gum/Vsed/2012_44/44/181-186.pdf (дата звернення: 04.02.2021).

10. Кадемія М. Ю., Шестопалюк О. В. Професійна підготовка педагогічних кадрів в умовах інноваційної перебудови української національної освіти: сучасний стан, проблеми, перспективи розвитку. Матеріали Міжвуз. наук.-практ. конф., 11 жовтня 2007 р. Харків : ХГПА, 2007. С. 82-86.

11. Коваль Л. Є. Електронний підручник як засіб вдосконалення професійної педагогічної освіти майстрів виробничого навчання. Наукові прайі. Серія «Педагогіка, психологія і соиіологія». 2010. № 8. С. 79-85.

\section{REFERENCES}

1. Hill J. R., Wiley D., Miller Nelson L., Ha, S. Exploring research on Internet-based learning: from infrastructure to interactions, in D. H. Jonassen (Ed.), Handbook of research for educational communications and technology, New Jersey, Lawrence Erlbaum associates, 2004, p. 433-460.

2. Kessler G. Technology and the future of language teaching. Foreign Language Annals, 51(2), 2018. p. 205-218. URL: https://www.researchgate.net/publication/323330702_Technology_and_the_future_of_language_teaching (date of request 1.02.2021)

3. Law C., So S. QR codes in education. Journal of Educational Technology Development and Exchange, 3(1), 2010. P. 85-100. URL: http://www.sicet.org/journals/jetde/jetde10/7-So.pdf (date of request 1.02.2021

4. Mills S. Using the Internet for active teaching and learning. Pearson/Merril/Prentice Hall, 2006. 220 p.

5. Mikulski J. 10 Ways to Use QR codes in the Classroom. Classroom in the Cloud. 2011. URL: http://www.classroominthecloud.net/2011/06/10-ways-to-use-qr-codes-in-classroom.html (date of request 2.02.2021)

6. Synekop O. WebQuest as Technology of Differentiated ESP Instruction at University Level. Journal of Teaching English for Specific and Academic Purposes, 8(1), 2020. 043-052. https://doi.org/10.22190/JTESAP2001043S (date of request 2.02.2021)

7. Sherman J., Thornbury S. Using Authentic Video in the Language Classroom (Cambridge Handbooks for Language Teachers). Cambridge University Press, 2010. 288 p

8. Gaidaienko I. Elektronnyi pidruchnyk yak novyi zasib podannia informatsii u navchal'nomu procesi. [Electronic textbooks as a new method of presentation in the educational process]. Naukovi zapysky Ternopil's'kogo natsional'nogo pedagogichnogo universytetu imeni Volodimyra Hnatiuka. [Scientific notes of V. Hnatiuk Ternopil national pedagogical university], History. 2(3), 2016. p. 162-170. URL: http://dspace.tnpu.edu.ua/handle/123456789/7380 (date of request 4.02.2021) [in Ukrainian]

9. Yesina, O. H. \& Linhur, L. M. (2012). Elektronni pidruchnyky: perevahy ta nedoliky vykorystannia. [Electrinic textbooks: advantages and frawbacks]. Visnyk sotsialno-ekonomichnykh doslidzhen [Bulletin of socio-economic research], № 1 (44), 2012. URL: http://www.nbuv.gov.ua/old_jrn/Soc_Gum/Vsed/2012_44/44/181-186.pdf. date of request 4.02.2021) [in Ukrainian]

10. Kademiya M. Yu. Elektronnij navchal'nij posibnik na interaktivnij osnovi. Profesijna pidgotovka pedagogichnih kadriv v umovah innovacijnoï perebudovi ukraïns'koï nacional'noï osviti: suchasnij stan, problemi, perspektivi rozvitku [Professional training of pedagogical staff in the conditions of innovative restructuring of the Ukrainian national education: current state, problems, prospects of development:]: materials of Interuni. scientif. And pract. konf., 11.10.2007. Khmelnytsk, 2007. p. 82-86. [in Ukrainian]

11. Koval, L. Ye. Elektronnyi pidruchnyk yak zasib vdoskonalennia profesiinoi pedahohichnoi osvity maistriv vyrobnychoho navchannia [Electronic textbook as a means of improving the professional pedagogical education of masters of industrial training]. Naukovi pratsi. Seriia: pedahohika, psykholohiia i sotsiolohiia [Scientific works. Series: pedagogy, psychology and sociology] № 8, 2010. P. 79-85 [in Ukrainian]. 